\title{
PREGABALIN DETERMINATION IN POSTMORTEM SAMPLES AND TOXICOLOGICAL SIGNIFICANCE IN FORENSIC CASES
}

\author{
Maja Vujovići,2, Emilija Kostić1 , Dimitrije Pančić1, Biljana Milosavljević2, Ivan Stojanović1,2, \\ Radovan Karadžić1,2, Goran Ilić1,2
}

\begin{abstract}
Pregabalin (PGB) was initially developed for epilepsy treatment, but nowadays its application has been expanded to neuropathic pain, anxiety disorder, and fibromyalgia. Unfortunately, over the past decade, PGB has migrated from a prescription drug to a novel recreational drug with considerable potential for abuse and intoxication worldwide. According to the data of the Institute Forensic Medicine Niš, the increase of PGB intoxications has also been noticed in the Southeast Serbia in recent years. Toxicological results of postmortem blood and urine samples obtained in the authors' laboratory in 2019 were primarily processed. Cases of intoxications with PGB, in combination with other psychoactive substances such as alcohol were included in this paper. All blood and urine samples were extracted using solid-phase extraction cartridges and forwarded to the chromatographic separation. Gas chromatography with mass spectrometry (GC/MS) was used for pregabalin determination, while liquid chromatography with tandem mass spectrometry (LC/MS), high-performance liquid chromatography with a photodiode array detector (HPLC/PDA), and headspace gas chromatography with flame ionization detector (HS-GC/FID) were used for other substance analysis. The PGB abuse has created concerns about risks of respiratory depression and death when used with opioids or other central nervous system depressants, such as drugs found in our investigated cases. Autopsy results showed that deaths were violent and the main cause of deaths was overdose with additive, depressive effects of drugs and alcohol on CNS. Consequently, health professionals must be aware of this misuse potential of PGB which could lead to dependence and overdose with a fatal outcome.
\end{abstract}

Acta Medica Medianae 2021;60(3):05-10.

Key words: pregabalin, postmortem samples, abuse, toxicology

${ }^{1}$ University of Niš, Faculty of Medicine, Niš, Serbia

${ }^{2}$ Institute of Forensic Medicine, Niš, Serbia

Contact: Maja Vujović

81 Dr Zoran Djindjić Blvd., 18000 Niš, Serbia

E-mail:maja.vujovic@medfak.ni.ac.rs

\section{Introduction}

Pregabalin (PGB) is a gamma-aminobutyric acid analogue with great structural similarity to gabapentin (GPT) (Figure 1).

The drug acts through excitatory neuronal transmission through ligands in voltage-sensitive calcium channels and reduces the release of excitatory neurotransmitters like glutamate and noradrenaline (1). The biochemical mechanism of action includes modulation of the $a 2 \delta$ subunit of the voltage-gated calcium channel (VGCC) from dorsal root ganglia to the spinal dorsal horn and blocking of trafficking of the $a 2 \delta$ subunit of the VGCC (2).
PGB as an anticolvusant drug was initially developed for the treatment of epilepsy $(1,3)$.

Nowadays, PGB is a drug used in the management of partial epilepsy, neuropathic pain, generalized anxiety disorder, and fibromyalgia (4). PGB is reported to stimulate feelings of sociability, euphoria, calm, and relaxation (5). It can enhance the psychoactive effects of other drugs, especially opioids, and also reduces withdrawal symptoms (6).

Recently, it has found usefulness in the management of alcohol withdrawal and benzodiazepine dependence, but some case reports and a few studies are causing ongoing debate on PGB's potential to cause addictive behaviours (6).

The status of pregabalin as a drug has changed during its existence.

Pregabalin was approved in 2004 in the United Kingdom (UK), since then it has become a widely prescribed drug (7). In the UK only, there was a $350 \%$ increase in the prescription of pregabalin from 2010 to 2015, and the very first death due to pregabalin was reported within 2 years of its application (8). 
<smiles>CC(C)C[C@H](CN)CC(=O)O</smiles>

a)<smiles>NCC1(CC(=O)O)CCCCC1</smiles>

b)

Figure 1. Chemical structure of a) pregabalin and b) gabapentin

(Source: http://www.chemspider.com/Chemical-Structure.4589156.html, http://www.chemspider.com/Chemical-Structure.3328.html?rid=f61caa31-9bd4-42ba-9cad-95f745feabe4)

In 2010, PGB abuse was first mentioned in reports from the European Monitoring Centre for Drugs and Drug Addiction (EMCDDA) (8).

The UK Advisory Council on the Misuse of Drugs (ACMD) first recommended placing PGB and GPT in class C Drugs under the Misuse of Drugs Act in 2016.

At the end of 2018, PGB was added to the list of psychoactive substances reviewed by the WHO $41^{\text {st }}$ Expert Committee on Drug Dependence (ECDD) because of its liability for abuse and dependence and its potential to cause public health and social harm. PGB was classified as having considerable "abuse liability". Over the past 10 years, PGB from a prescription drug has become a recreational drug. Online sources and the black market made it easily available (9).

In the region of Southeast Serbia, concerns about the risk for misuse of or dependence on pregabalin has been evident since 2015. According to results of toxicological data at the Institute of Forensic Medicine in Niš, intoxications with PGB in both clinical and postmortem samples have also been noticed in recent years. A higher prevalence of misuse is among psychiatric patients, drug abusers and prisoners (unpublished data).

The molar mass of PGB is $159.23 \mathrm{~g} / \mathrm{mol}$ and boiling point $144-147^{\circ} \mathrm{C}$. The effective dose of PGB is $150-600 \mathrm{mg} /$ day, while bioavailability is more than $90 \%$. PGB has an elimination half-life of $5.5-$ $6.7 \mathrm{~h}$, independent of dose and repeated dose administration. Pregabalin plasma clearance is essentially equivalent to renal clearance, indicating that pregabalin undergoes negligible nonrenal elimination. More than $90 \%$ of the drug is excreted by renal unchanged. Less than $1 \%$ is metabolised into $\mathrm{N}$ methylated derivative (10).

The therapeutic range for PGB is $0.4-17 \mathrm{mg} / \mathrm{L}$ in peripheral blood.

According to these statements, samples of choice for toxicological examinations are blood and urine, while the analysis method is gas chromatography with a mass spectrometer.

\section{Materials and methods}

The primary data consisted of toxicological results of blood and urine samples taken on forensic autopsies at the Institute of Forensic Medicine in Niš during 2019.

Three cases of intoxications with a combination of PGB (concentrations above the therapeutic range) and other drugs and alcohol were included in this paper. Data obtained from postmortem whole femoral blood and urine were considered.

All samples were kept refrigerated (between 2 and $8^{\circ} \mathrm{C}$ ) before the analysis.

Blood and urine samples were extracted using solid-phase extraction on Plexa, PCX, Agilent cartridges.

For the analysis of PGB and methadone, gas chromatography with mass spectrometry (GCMS-QP 2010 Shimadzu, Japan) was used, while for sildenafil and buprenorphine analysis liquid chromatography with tandem mass spectrometry (LCMS-8030 Triple Quad Shimadzu, Japan) was used.

High-performance liquid chromatography with a photodiode array detector (HPLC Alliance Waters, USA) was used for the determination of diazepam, nordazepam, oxazepam and alprazolam.

Alcohol concentration was analysed by headspace gas chromatography with flame ionisation detector (HS-GC/FID-2010 Shimadzu, Japan).

\section{PGB determination}

GC separation was carried out with a Shimadzu gas chromatograph QP 2010 system with ZB-5 column ( $30 \mathrm{~m} \times 0.25 \mathrm{~mm} ; 0.25 \mu \mathrm{m})$. The MS analysis was performed using Shimadzu mass spectrometer, in SCAN mode, while quantification was performed in SIM mode (m/z: 41, 56, 84, 141). For quantification, $\mathrm{m} / \mathrm{z} 141$ was used. The used software was Lab Solutions. The calibration range was from 0.5 to $25 \mathrm{mg} / \mathrm{L}$ with a limit of detection of 0.05 $\mathrm{mg} / \mathrm{L}$.

Mass spectrometer and gas chromatograph parameters were presented in Table 1. 
Table 1. Mass spectrometer and gas chromatograph parameters

\begin{tabular}{||c|c||c|c||}
\hline \multicolumn{2}{|c||}{ MS parameters } & \multicolumn{2}{c||}{ GC parameters } \\
\hline Ion Source & $200{ }^{\circ} \mathrm{C}$ & $\begin{array}{c}\text { Injection } \\
\text { Temperature }\end{array}$ & $275^{\circ} \mathrm{C}$ \\
\hline $\begin{array}{c}\text { Interface } \\
\text { Temperature }\end{array}$ & $280{ }^{\circ} \mathrm{C}$ & Injection Mode & Split \\
\hline Solvent Cut Time & $5 \mathrm{~min}$ & Split Ratio & 10 \\
\hline Threshold & 200 & Pressure & $107.2 \mathrm{kPa}$ \\
\hline Micro Scan Width & 0 & Column Flow & $1.5 \mathrm{~mL} / \mathrm{min}$ \\
\hline Detector Voltage & Relative to the Tuning Results & Purge Flow & $3 \mathrm{~mL} / \mathrm{min}$ \\
\hline Start Time & $5 \mathrm{~min}$ & Flow Control Mode & $\begin{array}{c}\mathrm{Linear} \text { velocity } \\
45.3 \mathrm{~cm} / \mathrm{sec}\end{array}$ \\
\hline End Time & $30 \mathrm{~min}$ & &
\end{tabular}

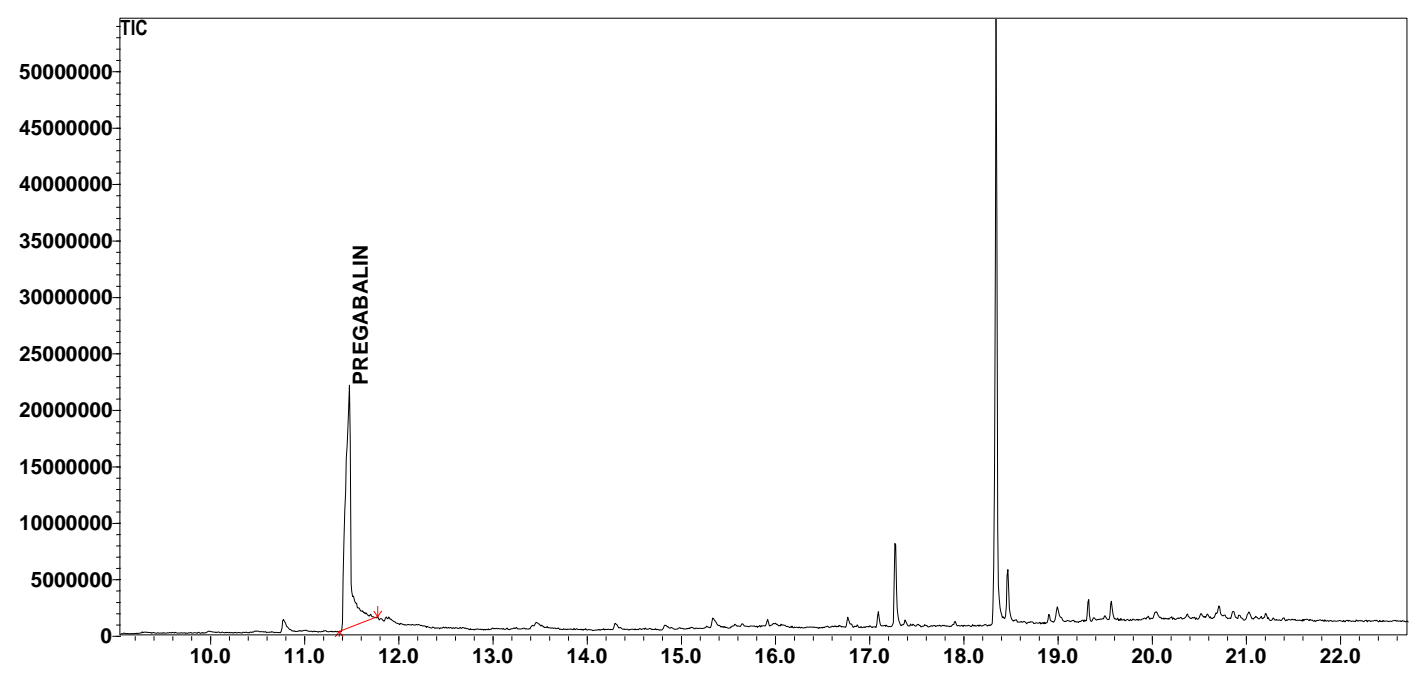

Figure 2. Typical chromatogram of urine sample

A

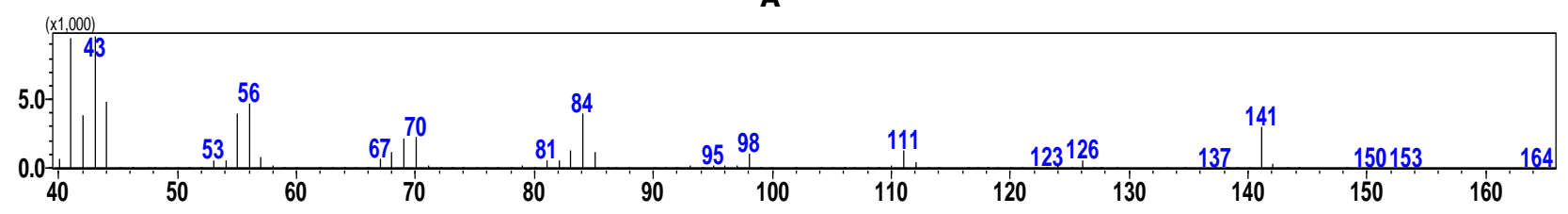

B

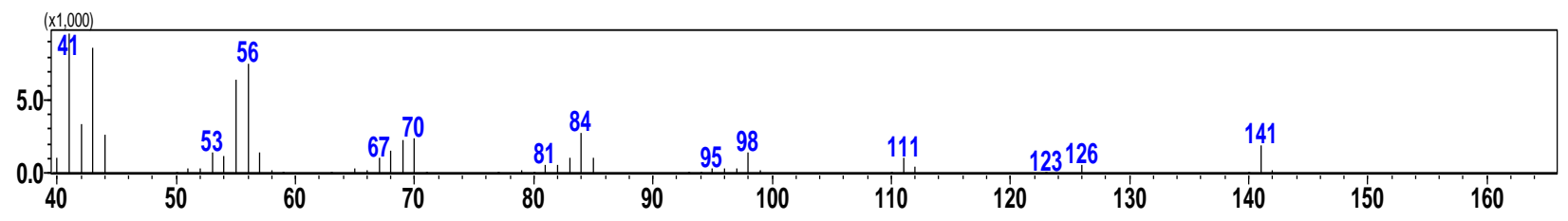

Figure 3. A) Mass spectum of target substance in urine sample and

B) Mass spectrum of pregabalin 


\section{Results}

Blood and urine samples of chosen cases were analysed using an adequate analytical technique. GC-MS chromatogram of urine sample of selected case is presented in Figure 2.

In Figure $3 \mathrm{~A}$, mass spectrum of target substance in urine sample is presented, while in Figure $3 \mathrm{~B}$, mass spectrum of pregabalin is presented.

\section{Case 1}

A male 23 years old, homeless, many times noticed under the influence of drugs and alcohol. His acquaintance gave information that he had taken many tablets of Lyrica (PGB) a day before. Concentrations of PGB in blood and urine samples were $64.8 \mathrm{mg} / \mathrm{L}$ and $2382 \mathrm{mg} / \mathrm{L}$, respectively. Diazepam $(0.51 \mathrm{mg} / \mathrm{L})$, nordazepam $(0.34 \mathrm{mg} / \mathrm{L})$ and methadone $(0.13 \mathrm{mg} / \mathrm{L})$ were determined in the whole blood. In urine, these drugs were below the limits of quantifications. As obtained results show, PGB was misused at many multiples of therapeutic ranges, at supratherapeutic doses, while concentrations of diazepam (anxiolytic) and methadone (opioid substitution) were in the therapeutic range. Autopsy results have shown the death was violent, with the exclusion of other pathological disorders or trauma injuries, and the main cause of death was overdose with additive, depressive effects of drugs on CNS.

\section{Case 2}

A male 22 years old was found dead the morning after a party. He was known as a drug abuser. The night before, he used Epica (PGB), Kamagra (sildenafil), Ernafil (sildenafil) and Ksalol (alprazolam). Concentrations of PGB in blood were $19.6 \mathrm{mg} / \mathrm{L}$ and in urine $260 \mathrm{mg} / \mathrm{L}$. Apart from PGB, alprazolam $(0.02 \mathrm{mg} / \mathrm{L})$ and sildenafil were detected in whole blood below limits of quantifications. In a urine sample, a metabolite of buprenorphine - norbuprenorphine (opioid substituent) was also detected. In the blood sample, there was $0.33 \mathrm{mg} / \mathrm{mL}$ of ethanol, while its concentration in urine samples was $1.20 \mathrm{mg} / \mathrm{mL}$. PGB concentration was a bit above the therapeutic range, but it depends on the tolerance of the patient. Alprazolam concentration was lower than toxic concentrations. At the time of death, the person was moderately intoxicated by alcohol. According to these results, it was concluded that the death was violent, with the exclusion of other pathological conditions or trauma injuries like in Case 1, and the main cause of death was overdose with additive, depressive effects of drugs and ethanol on CNS.

\section{Case 3}

A male 44 years old was treated at Mental Health Clinics as an opioid addict. Concentrations of PGB were $19.7 \mathrm{mg} / \mathrm{L}$ and $2800 \mathrm{mg} / \mathrm{L}$ in blood and urine samples, respectively. Diazepam (5.98 mg/L) and nordazepam concentrations $(15.76 \mathrm{mg} / \mathrm{L})$ were toxic, while oxazepam and buprenorphine were also detected. Apart from these drugs, norbuprenorphine was detected in urine. A high concentration of PGB in urine indicated that the dose of PGB the person took was many times higher than prescribed. Diazepam and nordazepam concentrations in the blood were also exceeded and toxic. Autopsy examination did not show significant pathological organic disorders or trauma injuries so as the main cause of death, which was by its nature violent, was listed an overdose and additive, depressive effects of drugs on CNS.

\section{Discussion}

Methadone and buprenorphine found in samples of all three people indicate that they were on opioid substitution therapy (OST). These drugs are partial opioid agonists. Diazepam and alprazolam are anxiolytics from benzodiazepine drug class, while nordazepam and oxazepam are diazepam's main metabolites. The main indication for alprazolam is agoraphobia. Sildenafil is a peripheral vasodilator, used for erectile dysfunction.

Diazepam, alprazolam, methadone and buprenorphine have depressive effects on the central nervous system (CNS). Apart from these drugs, the Case 2 person was also under the influence of ethanol, which also expresses depressive effects on CNS.

PGB concentrations in all cases were above the therapeutic range. Also, in a study conducted in the United Kingdom in 2016, from the PGB positive reports, $28.93 \%$ were above the therapeutic range (> $17 \mathrm{mg} / \mathrm{l}$ ). At higher dosage, it causes CNS depression, potentially causing drowsiness, sedation, respiratory depression and death (11).

Worldwide, an increase in the non-medical use of psychoactive prescription drugs including PGB was noticed. Opioid dependents administer PGB at high dosages to achieve euphoria, reduce withdrawal symptoms, or potentiate the effects of opioids and opioid substituents. PGB has been consumed concurrently with methadone to achieve an additional "high" effects (12). Recent results show the prevalence of PGB abuse up to $68 \%$ among opioids abusers (13). These are reasons for accurate toxicological monitoring for these high-risk individuals (14).

Besides opioids, PGB is taken in combination with alcohol, gabapentin, benzodiazepines and zopiclone (hypnotic), and to enhance the overall psychogenic effect. It has also been combined with cannabis, amphetamines, LSD, and mephedrone (9).

The abuse potential of PGB has created concerns about increased risks of respiratory depression and death when used with opioids or other central nervous system depressants, such as drugs found in our investigated cases. (15)

Hall et al. have conducted a survey in 2014 at Gold Coast Interdisciplinary Persistent Pain Centre (GCIPPC) and they noticed depression and suicidal ideation in $5 / 50$ people on the PGB therapy. Suicidal 
ideation is a recognized adverse effect of pregabalin (16).

\section{Conclusion}

Forensic autopsy results have shown that the deaths were violent and the main cause of deaths was overdose with additive, depressive effects of drugs and alcohol on CNS. Although there are cases of survival after intoxication with high amounts of PGB, the study shows that PGB abuse can be fatal, especially when combined with opioid substitutions, benzodiazepines and alcohol due to their combined depressive effect on the CNS.

The presented cases add to already prominent evidence that PGB is abused/misused alongside the other medications and alcohol. Therefore, prescribers need to consider the necessity of prescribing these drugs. Health professionals and prescribers must be aware of this misuse potential, which could lead to abuse, dependence or fatal outcome. Patients should be warned of and monitored for alteration in moods such as depression and suicidal ideations.

\section{References}

1. Toth C. Pregabalin: latest safety evidence and clinical implications for the management of neuropathic pain. Ther Adv Drug Saf 2014;5:38-56. [CrossRef] [PubMed]

2. Bauer CS, Nieto-Rostro M, Rahman W. The increased trafficking of the calcium channel subunit a $2 \delta-1$ to presynaptic terminals in neuropathic pain is inhibited by the a2 $\delta$ ligand pregabalin. J Neurosci 2009; 29(13):4076-88. [CrossRef] [PubMed]

3. Jacquy J, Lossignol D, Sternon J. Pregabalin (Lyrica) and neuropathic pain syndromes. Rev Med Brux 2006; 27:445-50. [PubMed]

4. Tassone DM, Boyce E, Guyer J, Nuzum D. Pregabalin: a novel gamma-aminobutyric acid analogue in the treatment of neuropathic pain, partial-onset seizures, and anxiety disorders. Clin Ther 2007;29:26-48. [CrossRef] [PubMed]

5. Feltner DE, Crockatt JG, Dubovsky SJ, Cohn CK, Shrivastava RK, Targum SD, et al. A randomized, double-blind, placebo-controlled, fixed-dose, multicenter study of pregabalin in patients with generalized anxiety disorder. J Clin Psychopharmacol 2003;23: 240-9. [CrossRef] [PubMed]

6. Gahr M, Franke B, Freudenmann RW, Kölle MA, Schönfeldt-Lecuona C. Concerns about pregabalin: further experience with its potential of causing addictive behaviors. J Addict Med 2013;7:147-9. [CrossRef] [PubMed]

7. Deeb S, McKeown DA, Torrance HJ, Wylie FM, Logan BK, Scott KS. Simultaneous Analysis of 22 Antiepileptic Drugs in Postmortem Blood, Serum and Plasma Using LC-MS-MS with a Focus on Their Role in Forensic Cases. J Anal Toxicol 2014;38:485-94. [CrossRef] [PubMed]

8. Robertson K. The EMCDDA annual report 2010: the state of the drugs problem in Europe. Euro Surveill 2010;15(46):19714. [CrossRef] [PubMed]
9. Lapeyre-Mestre M, Dupui M. Drug abuse monitoring: which pharmacoepidemiological resources at the European level? Therapie 2015;70:147-65. [CrossRef] [PubMed]

10. Bockbrader HN, Radulovic LL, Posvar EL, Strand JC, Alvey CW, Busch JA, Randinitis EJ, et al. Clinical pharmacokinetics of pregabalin in healthy volunteers. J Clin Pharmacol 2010;50(8):941-50. [CrossRef] [PubMed]

11. Nahar LK, Murphy KG, Paterson S. Misuse and Mortality Related to Gabapentin and Pregabalin are Being Under-Estimated: A Two-Year Post-Mortem Population Study. J Anal Toxicol 2019;43(7):564-70. [CrossRef] [PubMed]

12. Baird CRW, Fox P, Colvin LA. Gabapentinoid abuse in order to potentiate the effect of methadone: a survey among substance misusers. Eur Addict Res 2014; 20:115-8. [CrossRef] [PubMed]

13. Pergolizzi JV, Taylor RA, Bisney JF, LeQuang JA, Coluzzi F, Gharibo CG. Gabapentinoid Use Disorder: Update for Clinicians. EC Anaesth 2018;4:303-17.

14. Lancia M, Gambelunghe A, Gili A, Bacci M, Aroni K, Gambelunghe $C$. Pregabalin Abuse in Combination With Other Drugs: Monitoring Among Methadone Patients. Front Psychiatry 2019;10:1022. [CrossRef] [PubMed]

15. Bonnet U, Scherbaum N. How addictive are gabapentin and pregabalin? A systematic review. Eur Neuropsychopharmacol 2017;27:1185-215. [CrossRef] [PubMed]

16. Hall TD, Shah S, Ng B, Feberwee HM, Dotchin L, Vandermost $M$, et al. Changes in mood, depression and suicidal ideation after commencing pregabalin for neuropathic pain. Aust Fam Physician 2014;43:705-8. [PubMed] 


\title{
ODREĐIVANJE PREGABALINA U POSTMORTEM UZORCIMA I TOKSIKOLOŠKI ZNAČAJ U SUDSKO-MEDICINSKIM SLUČAJEVIMA
}

\author{
Maja Vujović1,2, Emilija Kostić1 ${ }^{1}$ Dimitrije Pančić1, Biljana Milosavljevićn ${ }^{2}$ Ivan Stojanović1,2, \\ Radovan Karadžić1,2, Goran Ilić1,2
}

\author{
${ }^{1}$ Univerzitet u Nišu, Medicinski fakultet, Niš, Srbija \\ ${ }^{2}$ Zavod za sudsku medicinu, Niš, Srbija \\ Kontakt: Maja Vujović \\ Bulevar dr Zorana Đinđića 81, 18000 Niš, Srbija \\ E-mail: maja.vujovic@medfak.ni.ac.rs
}

Pregabalin (PGB) je lek inicijalno razvijen za tretman epilepsije, ali danas se primena proširila i na lečenje neuropatskog bola, anksioznih poremećaja i fibromialgije. Nažalost, tokom poslednjih 10 godina, PGB je širom sveta počeo da bude zloupotrebljivan, sa značajnim potencijalom izazivanja zavisnosti i ozbiljnih trovanja. Prema obrađenim podacima Zavoda za sudsku medicinu u Nišu, poslednjih godina, takođe je primećen porast intoksikacija PGB-om u jugoistočnom delu Srbije. U ovom radu obrađeni su rezultati toksikološko-hemijskih analiza krvi i urina postmortem slučajeva u 2019. godini. Obuhvaćene su intoksikacije PGB-om, u kombinaciji sa drugim psihoaktivnim supstancama i alkoholom. Svi uzorci krvi i urina ekstrahovani su tečno-čvrstom ekstrakcijom, a zatim hromatografski razdvojeni. Za određivanje pregabalina korišćena je gasna hromatografija sa masenom spektrometrijom (GC/MS), dok su tečna hromatografija sa tandem masenom spektrometrijom (LC/MSMS), zatim tečna hromatografija visokih performansi sa photo-diode array detektorom (HPLC/PDA) i headspace gasna hromatografija sa plameno-jonizacionim detektorom (HS-GC/FID) primenjene za analizu drugih supstanci. Zbog raširene zloupotrebe PGB-a, povećana je zabrinutost zbog rizika od respiratorne depresije i smrti, kada se koristi u kombinaciji sa opioidima ili drugim depresorima centralnog nervnog sistema, kao što su lekovi čiji su negativni efekti prikazani u analiziranim slučajevima. Rezultati obdukcije pokazali su to da smrtni slučajevi nisu bili nasilni, a glavni uzrok smrti je predoziranje aditivnim, depresornim efektom lekova i alkohola na centralni nervni sistem. Shodno tome, zdravstveni radnici moraju biti svesni potencijalne zloupotrebe PGD-a, koji može dovesti do zavisnosti i teških trovanja sa fatalnim ishodom.

Acta Medica Medianae 2021;60(3):05-10.

Ključne reči: pregabalin, postmortem uzorci, zloupotreba, toksikologija 